\title{
TESTICULAR HYPOPLASIA AND XXY SEX CHROMOSOME COMPLEMENT IN TWO RAMS: THE OVINE COUNTERPART OF KLINEFELTER'S SYNDROME IN MAN
}

\author{
A. N. BRUERE, R. B. MARSHALL AND D. P. J. WARD \\ Department of Veterinary Clinical Science, Massey University, \\ Palmerston North, New Zealand
}

(Received 27th May 1968)

\begin{abstract}
Summary. Two sheep of different breed displayed gross testicular hypoplasia, azoospermia, and apparent aspermatogenesis. The modal chromosome number was 55 in all tissues studied, the extra chromosome being identified as an $\mathrm{X}$ from sex chromatin studies on one animal. The abnormalities resemble those of chromatin-positive Klinefelter's syndrome in man, with a comparable incidence and a possibly identical cause in the two species.
\end{abstract}

\section{INTRODUCTION}

Testicular hypoplasia is not uncommon in the ram. It was present in $3.5 \%$ of over 9000 rams examined by Gunn, Sanders \& Granger (1942). Some forms of testicular hypoplasia were undoubtedly due to atrophy following an acute infection, e.g. ovine brucellosis (Buddle, 1956) or ovine actinobacillosis (Baynes \& Simmons, 1960). Others, however, were probably similar to the cases of extreme, symmetrical, bilateral testicular hypoplasia reported by veterinarians after routine genital examination of rams in Australasia. This condition is of unknown aetiology. Similar findings have been reported in the bull, and the incidence was as high as $5 \%$ for bulls of Swedish Highland cattle (Lagerlof, 1951).

We considered that the aetiology of testicular hypoplasia in some rams was probably analogous to chromatin-positive Klinefelter's syndrome in man (Jacobs \& Strong, 1959; Ford, Jones, Miller, Mittwoch, Penrose, Ridler \& Shapiro, 1959; Ferguson-Smith, Lennox, Mack \& Stewart, 1957; FergusonSmith, 1958, 1959). This latter condition occurs in approximately $I$ in 400 male births and is characterized by sterility, small testicles (micro-orchidism), gynecomastia in some cases and high urinary gonadotrophin excretion.

In Klinefelter's syndrome, the chromosome number is 47 instead of the normal diploid number of 46 . The extra chromosome is an $\mathrm{X}$ which affects the phenotype producing the characteristic micro-orchidism and associated testicular pathology. These cases are referred to as chromatin-positive due to the presence of a sex chromatin body which can be seen in resting somatic cell 
nuclei and which represents the extra but 'inactivated' $\mathrm{X}$ chromosome of the karyotype. However, some cases of Klinefelter's syndrome in man are chromatinnegative and are not associated with chromosome imbalance.

As well as the usually infertile XXY chromatin-positive Klinefelter's syndrome, mosaic chromosome patterns of which the XY/XXY group is most common, have been described and are sometimes associated with male fertility (Court-Brown, Harnden, Jacobs, MacLean \& Mantle, 1964; Ferguson-Smith, 1966).

Chromatin-positive Klinefelter's syndrome has been described in the mouse (Ferguson-Smith, 1966), the cat (Chu, Thuline \& Norby, 1964; Thuline \& Norby, 1968) and the pig (Harvey, personal communication). Five different chromosome patterns $\mathrm{XXY}, \mathrm{XX} / \mathrm{XY}, \mathrm{XX} / \mathrm{XY} / \mathrm{XXY}, \mathrm{XX} / \mathrm{XYY}$ and $\mathrm{XX} / \mathrm{XXY}$ have been reported in the cat but there was no predominance of $X X Y$ cases as is seen in man.

The two rams to be described are of particular interest as they were selected from a group of six showing uniform bilateral testicular hypoplasia. Further, they came from the clinical rejection within only one veterinary practice.

\section{MATERIALS AND METHODS}

\section{$\operatorname{Ram} A$}

This was a Romney ram aged 15 months from a stud where rams were found sporadically with testicular hypoplasia. These animals did not appear to have a familial relationship. The ram was smaller than, though similar in conformation to, other 15-month rams in the flock. It showed strong male libido towards ewes in oestrus and performed the physical actions of ejaculation. The small scrotum appeared to be empty but contained two small symmetrical testicles near the external inguinal ring.

\section{$\operatorname{Ram} B$}

This was a Cheviot ram also aged 15 months. Like the previous ram, there was no familial relationship with other possible cases of hypoplasia. Its genitalia and libido were similar to those of Ram A.

\section{Chromosome studies}

Mitotic chromosome preparations were made from both leucocyte cultures and fibroblast cultures.

Leucocyte cultures. The method followed was similar to that of Basrur \& Gilman (1964). Chromosome preparations were made from cultures subjected to hypotonic treatment with a $0.075 \%$ solution of $\mathrm{KGl}$ for $10 \mathrm{~min}$ (Hungerford, 1965). Cells were resuspended in alcohol-acetic acid (3:1), followed by alcoholacetic acid $(3: 2)$ fixative. Air dried slides were stained in Geimsa and examined microscopically.

Fibroblast cultures. Small pieces of gonad and kidney from the fresh cadaver of Ram A and from a testis in Ram B, were cut into $1-\mathrm{mm}$ fragments and treated with $0.25 \%$ trypsin solution. Cells were cultured in $100-\mathrm{ml}$ medical flat bottles using a media of Hank's balanced salt solution, $10 \%$ calf serum, $0.5 \%$ lactal- 
bumen hydrolysate, $10 \%$ tryptose phosphate broth, and $5 \%$ yeast extract. In addition, 50 i.u. of benzyl penicillin plus $50 \mu \mathrm{g}$ streptomycin sulphate $/ \mathrm{ml}$ of medium were added and the $\mathrm{pH}$ of the medium adjusted to 7.2 with $4.4 \%$ sodium bicarbonate.

Cultures were incubated at $37^{\circ} \mathrm{C}$ for 3 to 14 days, then split and subcultured for a further 12 to $24 \mathrm{hr}$. Nine hours before harvesting, $0.2 \mathrm{ml}$ of colchicine $(100 \mu \mathrm{g} / \mathrm{ml})$ was added. Chromosome preparations were made as described above.

Sex chromatin studies

For sex chromatin studies, sections of spinal cord cut at $10 \mu$ were stained with cresyl echt violet (Coleman and Bell) and examined at $\times 1000$ (Moore \& Barr, 1953; Bruere, 1966). Chromatin bodies were counted only in the large ventral horn nerve cells.

\section{Histology}

Sections of gonadal tissue were fixed in formol alcohol (absolute ethanol 90 $\mathrm{ml}$, acetic acid $5 \mathrm{ml}$, formalin $10 \mathrm{ml}$ ) embedded in paraffin wax, cut at $6 \mu$ and stained with haematoxylin and eosin. In addition, some gonadal material was fixed in Carnoy's fixative No. 2 (Culling, 1963) and following routine embedding, was stained with a modified Sheridan's stain (Puchtler \& Sweat, 1964).

\section{RESULTS}

\section{Chromosome and sex chromatin studies}

From the leucocyte cultures the modal chromosome number counted in Ram A and Ram B was 55 in $58.52 \%$ and $76.31 \%$ of metaphases, respectively (Table 1). This falls outside the range of modal cells previously counted in normal sheep in which the modal chromosome number is 54 (McFee, Banner \& Murphree, 1965; Bruere \& McLaren, 1967). The additional chromosome was present in a high percentage of metaphases in all other tissues cultured. It can be seen from the karyotype (Pl. 1, Fig. 1) that the extra chromosome was acrocentric and probably an X chromosome. This interpretation was confirmed in Ram A when a sex chromatin body was seen in 159 of 228 cells counted $(69.73 \%)$, a figure similar to the percentage of chromatin-positive cells counted in normal ewes (Bruere, 1966). Autoradiographic studies have similarly shown a large, late-replicating, acrocentric chromosome similar to the late-replicating $\mathrm{X}$ chromosome in human Klinefelter's syndrome (unpublished observations).

\section{Anatomical and histopathological findings}

The testes from both rams were nearly the same size. Those of Ram A (left testis $37.0 \mathrm{~g}$; right testis $38.0 \mathrm{~g}$ ) were approximately $13.7 \%$ of the testis weight $(276 \mathrm{~g})$ recorded for a normal ram of the same age (Pl. 1, Fig. 2). Although smaller than normal testes, hypoplastic gonads appeared anatomically normal and symmetrical. The term micro-orchidism used by Ferguson-Smith (1959) is appropriate. 
Histologically, the gonads showed small seminiferous tubules lined by a single layer of well-differentiated Sertoli cells (Pl. 2, Fig. 3). The number of Leydig cells was apparently increased, but the effective androgen secreting tissue was probably much less than that of a normal ram because of the reduced size of the testes. The ghost tubules described in human cases (Ferguson-Smith, 1958) were not seen, but certain areas in the testis of Ram A showed clusters of immature tubules containing undifferentiated Sertoli cells (P1. 2, Fig. 4). The elastic fibre staining techniques showed normal distribution of elastic tissue in

TABLE 1

CHROMOSOME COUNTS FROM TWO RAMS SHOWING TESTICULAR HYPOPLASIA

\begin{tabular}{|c|c|c|c|c|c|c|c|c|c|}
\hline & 50 & 51 & 52 & $\begin{array}{c}\text { Chromo } \\
53\end{array}$ & $\begin{array}{c}\text { ome num } \\
54\end{array}$ & 55 & 56 & Poly & Total \\
\hline $\begin{array}{l}\text { Ram A } \\
\text { Leucocyte Culture } 1 \\
\text { Leucocyte Culture } 2 \\
\text { Total } \\
\% \text { Cells in each }\end{array}$ & $\begin{array}{l}3 \\
3 \\
1 \cdot 43\end{array}$ & $\begin{array}{l}5 \\
1 \\
6 \\
2 \cdot 86\end{array}$ & $\begin{array}{l}5 \\
1 \\
6 \\
2 \cdot 86\end{array}$ & $\begin{array}{l}11 \\
1 \\
12 \\
5 \cdot 71\end{array}$ & $\begin{array}{l}51 \\
2 \\
53 \\
25 \cdot 24\end{array}$ & $\begin{array}{c}95 \\
28 \\
123 \\
58 \cdot 52\end{array}$ & $\begin{array}{l}1 \\
1 \\
2 \\
0 \cdot 95\end{array}$ & 二 & $\begin{array}{r}175 \\
35 \\
210 \\
-\end{array}$ \\
\hline $\begin{array}{l}\text { Testis Culture } 1 \\
\text { Testis Culture } 2 \\
\text { Kidney Culture } 1 \\
\text { Total } \\
\% \text { Cells in each }\end{array}$ & $\begin{array}{l}\bar{z} \\
=\end{array}$ & $\begin{array}{l}1 \\
1 \\
2 \\
2 \cdot 96\end{array}$ & $\begin{array}{l}1 \\
1 \\
1 \\
3 \\
4 \cdot 41\end{array}$ & $\begin{array}{l}1 \\
1 \\
3 \\
5 \\
7 \cdot 35\end{array}$ & $\begin{array}{l}\overline{6} \\
2 \\
8 \\
11 \cdot 76\end{array}$ & $\begin{array}{l}7 \\
32 \\
10 \\
49 \\
72 \cdot 06\end{array}$ & $\begin{array}{l}E \\
z \\
-\end{array}$ & $\frac{1}{1-}$ & $\begin{array}{r}9 \\
42 \\
17 \\
68 \\
-\end{array}$ \\
\hline $\begin{array}{l}\text { RaM B } \\
\text { Leucocyte Culture } 1 \\
\text { Leucocyte Culture } 2 \\
\text { Total } \\
\% \text { Cells in each }\end{array}$ & $\frac{1}{1}$ & $\frac{4}{4}$ & $\begin{array}{l}4 \\
2 \\
6 \\
5 \cdot 26\end{array}$ & $\begin{array}{l}3 \\
1 \\
4 \\
3 \cdot 51\end{array}$ & $\begin{array}{l}6 \\
3 \\
9 \\
7 \cdot 89\end{array}$ & $\begin{array}{l}51 \\
36 \\
87 \\
76 \cdot 31\end{array}$ & $\begin{array}{l}1 \\
1 \\
0.88\end{array}$ & $\begin{array}{l}1 \\
1 \\
2 \\
1 \cdot 76\end{array}$ & $\begin{array}{r}71 \\
43 \\
114 \\
\end{array}$ \\
\hline $\begin{array}{l}\text { Testis Culture } \\
\% \text { Cells in each }\end{array}$ & $\begin{array}{l}1 \\
1.67\end{array}$ & $\begin{array}{l}2 \\
3 \cdot 33\end{array}$ & $\begin{array}{l}3 \\
5 \cdot 0\end{array}$ & $\begin{array}{l}3 \\
5 \cdot 0\end{array}$ & $\begin{array}{c}9 \\
15 \cdot 0\end{array}$ & $\begin{array}{l}42 \\
70 \cdot 0\end{array}$ & - & 二 & $\underline{60}$ \\
\hline
\end{tabular}

the tunica propria (Pl. 2, Fig. 5). There was no evidence of hyalinization of the tubular basement membrane as reported in man (de la Balze, Bur, ScarpaSmith \& Irazu, 1954).

\section{DISCUSSION}

The results establish clearly that in the ram, as in man, primary micro-orchidism or extreme bilateral testicular hypoplasia can be associated with an extra $\mathrm{X}$ chromosome. The chromosome counts made suggest that there may have been mosaicism within tissues, but the sex chromatin studies in Ram A do not support this. This anomaly may have arisen because of the hypotonic technique used in our laboratory. A larger proportion of metaphases was fragmented by this method than by $0.7 \%$ sodium citrate as used previously (Bruere, 1966). This effect of treatment by $\mathrm{KCl}$ has been observed in other cytogenetics laboratories (Veale, personal communication). In the large number of cases reported by Court-Brown et al. (1964), presumptive mosaicism was only claimed when the modal count deviated significantly from normal. In the present studies, it was not possible to decide from karyotype analysis of cells with 54 chromosomes whether the missing acrocentric chromosome was an X. In some metaphases 
PLATE 1

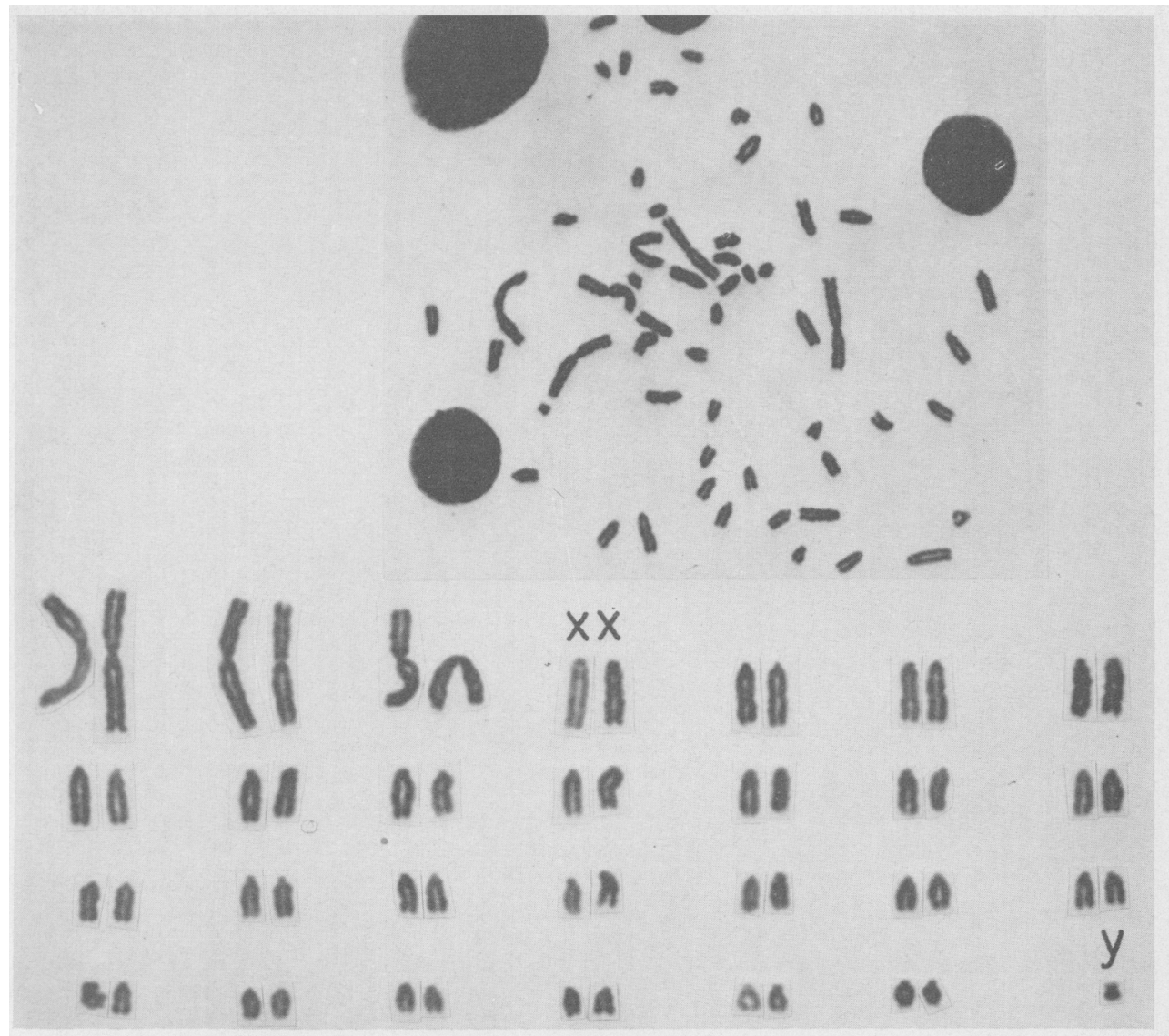

Fig. 1 (above). The karyotype of one of the rams with an XXY sex chromosome complement. The XX chromosomes are two of the large acrocentric chromosomes. $\times 2500$.

Fic: 2 (right). A testicle from Ram A compared with that of a normal Romney 15month ram from the same flock. The scale is graded in centimetres.

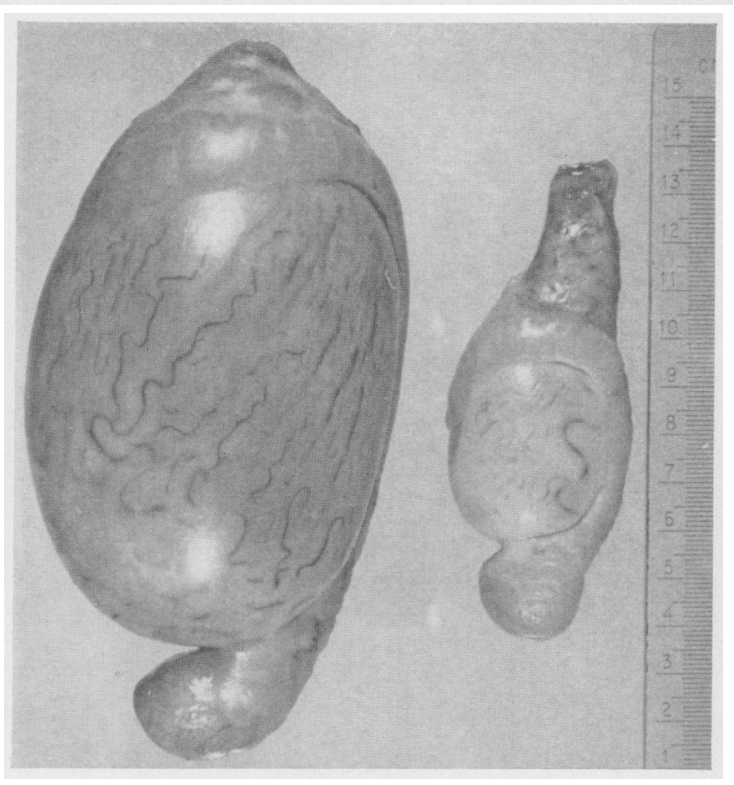

(Facing p. 106) 
PIATE 2
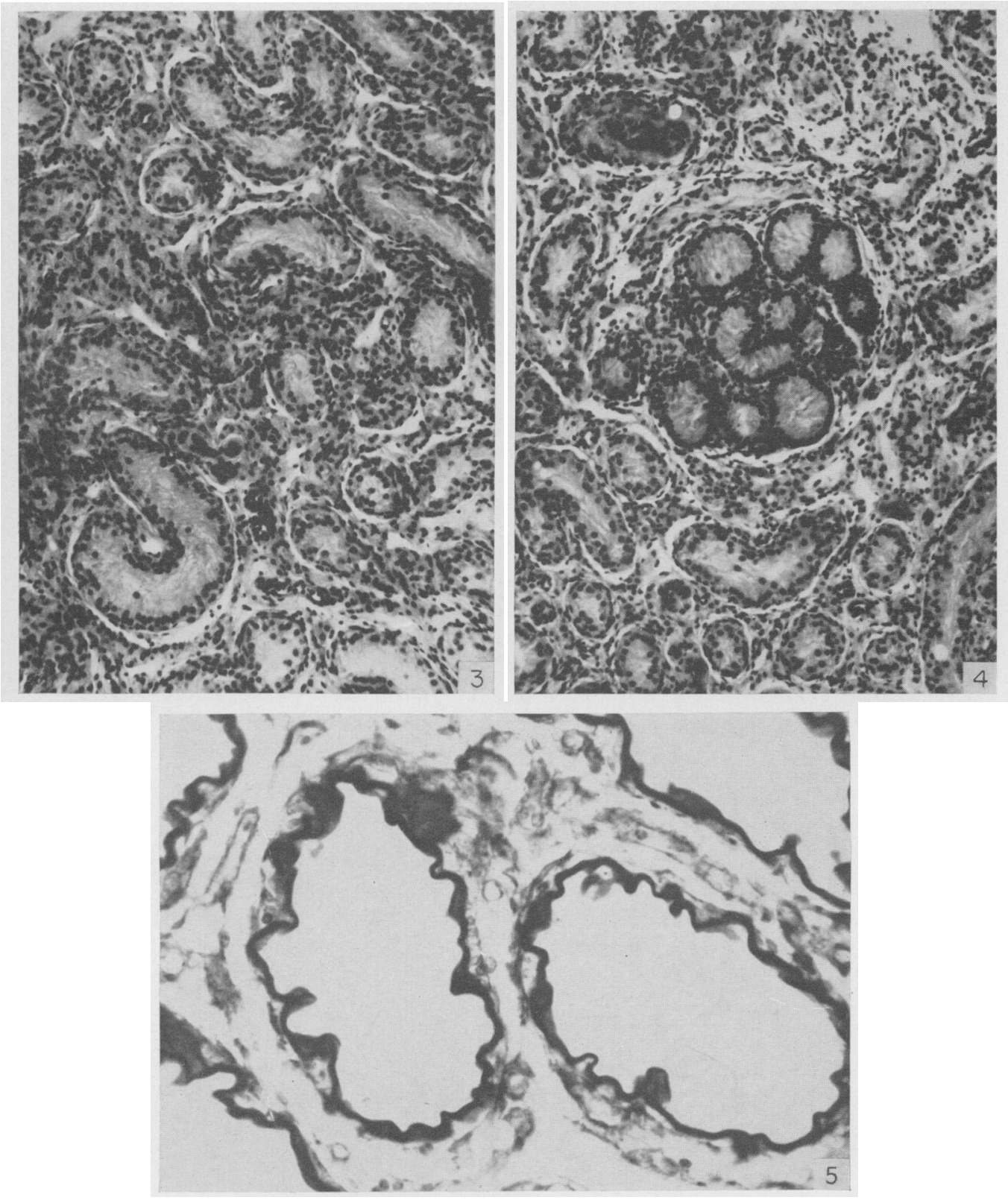

Fess. 3 and 4. Sections of the gonad of Ram A. Note the increased Leydig cells and absence of spermatogenesis. In Fig. 4 a cluster of tubules with incompletely differentiated Sertoli calls is shown. $\times 100$.

Fici. 5. Section of gonad using a modified Sheridan's stain for elastin. The amount of elastic tissue demonstrated is comparable to that of a normal ram of the same age. $\times 200$. 
however, one probable $\mathrm{X}$ chromosome could be identified by its greater length, but homologue asymmetry obscured the other, if it was present. The origin of the micro-orchidism in the two rams described was probably similar to that suggested for an XXY human, namely non-disjunction of the $\mathrm{X}$ chromosome during spermatogenesis and subsequent fusion of the resultant $\mathrm{X}$ - and $\mathrm{Y}$-bearing spermatozoon with an ovum bearing normal chromosomes or vice versa (Ferguson-Smith, 1961).

In the ram, the extra $\mathrm{X}$ chromosome would appear to inhibit testicular development and spermatogenesis more than it does in man. Ferguson-Smith (1966) quotes the human gonad in Klinefelter's syndrome as being approximately half the size of a normal male testicle, but, in our rams, abnormal testicles were one ninth of the normal size. In addition, the two sheep studied showed azoospermia, whereas in man, even in XXY Klinefelter's syndrome, occasional tubules showing complete spermatogenesis are not a rare occurrence (Ferguson-Smith, personal communication).

It was not possible to measure the urinary excretion of gonadotrophins nor to assess the activity of the Leydig cells in secreting androgen in either of these rams. Clinically, however, from the unimpaired libido of both rams, there appeared to be no androgen deficiency.

The significance of micro-orchidism as a cause of sterility in the ram is emphasized by the ease with which the above two cases were found. In the sheep, sex chromatin studies are of no value in preliminary screening of suspected animals as they are in man because sex chromatin can not be demonstrated in buccal smears (Struck, 1961; Bruere, 1966). It will be valuable, however, in the future to examine karyotypically all rams with testicular hypoplasia, particularly for chromosome mosaics which may be present and associated with partial spermatogenesis.

Note added in proof. Since these two rams were studied a further phenotypically identical Romney two tooth ram has been found by the authors which has 55 chromosomes in metaphases from leucocyte culture.

\section{ACKNOWLEDGMENTS}

The authors wish to thank Miss Robyn Fleming and Mrs Denise Udy for expert technical assistance, Mr G. H. Burns for photographs of animal gonads, Mr G. Sommerville and Mr R. Berry for providing the animals and $\mathrm{Mr} \mathrm{G}$. Martin of Romney Marsh Survey for assistance in many ways.

\section{REFERENCES}

BasRur, P. K. \& Gilman, J. P. W. (1964) Blood culture method for the study of bovine chromosomes. Nature, Lond. 204, 1335.

Baynes, I. D. \& Simmons, G. C. (1960) Ovine epididymitis caused by Actinobacillius seminis, n. sp. Aust. vet. F. 36, 454.

Bruere, A. N. (1966) A study in cytogenetics in the sheep. Ph.D. thesis, Glasgow University Library, Glasgow, Scotland.

BRUERe, A.N. \& McLaren, R. D. (1967) The idiogram of the sheep with particular reference to secondary constrictions. Can. F. Genet. Cytol. 9, 543. 
Budde, M. B. (1956) Studies in Brucella ovis (n.sp.) A cause of genital disease of sheep in New Zealand and Australia. 7. Hyg., Camb. 54, 351.

ChU, E. H. Y., Thut,INe, H. C. \& NorBy, D. E. (1964) Triploid-diploid chimerism in a male tortoiseshell cat. Cytogenetics, $3,1$.

Gourt-Brown, W. M., Harnden, D. G., Jacobs, P. A., Maclean, N. \& Mantle, D. J. (1964) Abnormalities of the sex chromosome complement in man. Spec. Rep. Ser. med. Res. Coun. 305.

Culling, C. F. A. (1963) Handbook of histopathological techniques, 2nd edn. Butterworths, London.

de la Balze, F. A., Bur, G. E., Scarpa-Smith, M. D. \& Irazu, J. (1954) Elastic fibres in the tunica propria of normal and pathological human testes. F. clin. Endocr. 14, 626.

Ferguson-Smith, M. A. (1958) Chromatin positive Klinefelter's syndrome (Primary micro-orchidism) in a mental deficiency hospital. Lancet, $\mathbf{i}, 928$.

Ferguson-Smith, M. A. (1959) The prepubertal testicular lesion in chromatin positive Klinefelter's syndrome (Primary micro-orchidism) as seen in mentally handicapped children. Lancet, i, 219.

Ferguson-Smith, M. A. (1961) Chromosomes and human disease. In: Progress in Medical Genetics. Ed. Arthur G. Steinberg. Grune \& Stratton, New York.

Ferguson-Smith, M. A. (1966) Sex chromatin, Klinefelter's syndrome and mental deficiency. In: The Sex Chromatin. Ed. K. L. Moore. Saunders, Philadelphia.

Ferguson-Smitr, M. A., Lennox, B., Mack, W. S. \& Stewart, J. S. S. (1957) Klinefelter's Syndrome: Frequency and testicular morphology in relation to nuclear sex. Lancet, $\mathbf{i i}, 167$.

Ford, C. E., Jones, K. W., Miller, O. J., Mrttwoch, U., Penrose, L. S., Ridler, M. \& Shapiro, A. (1959) The chromosomes in a patient showing both mongolism and the Klinefelter's syndrome. Lancet, i, 709.

Gunn, R. M. G., Sanders, R. N. \& Granger, W. (1942) Studies in fertility in sheep. Bull. Coun. scient. ind. Res. Melb. 148.

Hungerford, D. A. (1965) Leucocytes cultured from small inocula of whole blood and the preparation of metaphase chromosomes by treatment with hypotonic KCl. Stain Technol. 40, 333.

Jacobs, P. A. \& Strong, J. A. (1959) A case of human intersexuality having a possible XXY sex determining mechanism. Nature, Lond. 183, 302.

LAGerLor, N. (1951) Hereditary forms of sterility in Swedish cattle breeds. Fert. Steril. 2, 230.

McFee, A. F., Banner, M. W. \& Murphree, R. L. (1965) Chromosome analysis of peripheral leucocytes of the sheep. 7. Anim. Sci. 24, 551.

Moore, K. L. \& BARR, M. L. (1953) Morphology of the nerve cell nucleus in mammals with special reference to sex chromatin. 7. comp. Neurol. 98, 213.

Puchtler, H. \& Sweat, F. (1964) A selective stain for renal basement membranes. Stain Technol. $39,163$.

STRUCK, F. (1961) Vergleichende untersuchunger über das Geschlechtschromatin bei einigen Haustieren mit Hilfe des Bucaltests. Z. Zellforsch. 55, 662.

Thuline, H. G. \& NorBy, D. E. (1968) Cytogenetic anomalies in male tortoise-shell cats: Five types and discussion of possible etiologic mechanisms. Mammalian Chromosome Newsletter, 9, 47. (Authors permission to quote). 